\title{
Historical experience and religious experience: a dialogue
}

\section{Short communication}

This presentation is an attempt to put together and reflect upon two topics that, in my view, are interrelated, though they might not have meant to be in first place: historical experience and religious experience. Historical experience is one of the most important themes in Frank Ankersmit's work-and one of the topics of my Ph.D. dissertation, which is about Ankersmit's intellectual journey. As we shall see in a moment, 'historical experience' in the Ankersmitean sense is a rare and complex kind of experience, entirely different from the experiences we have in our daily lives or from experience in the empiricist sense; for it presupposes the possibility for the historian to be in direct contact with a past that is long gone. But can we really experience the past? How could a historian perform something like this? On the other hand, there is the 'religious experience', which is a much more common kind, at least because we hear more often about it. I am thinking here of the kind of experience that, like historical experience, has to do with sublime and extraordinary things, like miracles or epiphanies, that may happen in the life of those who believe in extraordinary things coming from the "realm of the transcendent", the "sphere of the Sacred", or from heaven.

Many religious people claim to have had in the past (or in the present) some kind of 'direct experience' with the Sacred, like, for instance, St. Paul's well-known experience of conversion on the Damascus road (reported in the Book of Acts in the New Testament, in which he was blinded by some light and heard the voice of Jesus Christ himself). So, in the religious realm (though most of my examples here will come from Christianity) this is not an odd thing at all, for the belief in the possibility of having these experiences is part of being a religious or "spiritual" person-especially in the present condition, within which spiritual experiences are welcome again after a short period of exile.

The same does not happen with historical experience. A historian is not supposed to have a historical experience (in Ankersmit's sense of it) to become a historian. The historian is usually seen as such if he/she offers a reliable account of a certain part of the past, with the proper abilities and procedures with and for which he/she was trained. According to the wisdom of the narrativist philosophy of history (on which Ankersmit relied in an earlier phase of his work), there is no escape from the confines of language, while having a historical experience means going beyond the 'prisonhouse of language' (in Nietzsche's famous words).

So, Ankersmit's account of experience is at odds with narrativism and the so-called linguistic turn, as I will show. But would it be the same with experience in a religious or spiritual sense? What those interested to understand the possibilities and the limits of religious experience can learn from historical experience? This might be the main question of this presentation.

In 2005, Ankersmit ${ }^{1}$ published his book Sublime Historical Experience, which for me is the second most important book of his career, for, as much as the first (most important) one, Narrative
Volume I Issue 3 - 2017

\author{
Jonathan Menezes \\ South American Theological Faculty, State University of Sao \\ Paulo, Londrina, Brazil
}

Correspondence: Jonathan Menezes, State University of Sao Paulo, Brazil, Email jonathan@ftsa.edu.br

Received: November 13, 2017 | Published: November 21, 2017

Logic, ${ }^{2}$ it represented a turning point in the contemporary philosophy of history (not for everybody, of course).

In Narrative Logic, Ankersmit thought that philosophy of history badly needed to turn linguistic in order to move the discussions forward, paying more attention to the 'semantics of the historian's language' (as stated in the book's subtitle) and to what happens on the level of the (historical) text, towards which philosophy of history and historiography has remained 'blind' until then.

On the other hand, the discontentment present in the book of 2005 was provoked precisely by everything (even part of his own theorizations) that previously came under the 'linguistic' umbrella. For, according to Ankersmit, "what all these theories have in common is the conviction of the impossibility of a direct access to the past; the past became hidden behind an impenetrable screen of language'. This is, by the way, one of the reasons for his interest in the notion of historical experience. For 'historical experience or historical sensation (as the Dutch historian Huizinga) put it restores [or, at least, is supposed to restore (J.M.)] this immediate and direct contact with the past' Ankersmit. ${ }^{3}$ (I will come back to Huizinga and historical sensation later).

There are certainly many ways of approaching Ankersmit's understanding of historical experience. I will try to summarize it here using his explanation about the idea of sublime dissociation of the past. What Ankersmit ${ }^{1}$ called 'the talent of dissociation' has to do with 'being able to momentarily discard from yourself all that you think to be essential to you and to your identity'. However, he recognizes that this might be one of the most counterintuitive abilities since the art of being human is 'the art of association', that is: 'our identities, all our conceptions of the world, of history and historical writing, for that matter, are all the product of association' Ankersmit.

Historical experience, on the other hand, is a moment of dissociation of our identity-as if you were out of yourself-so, it is an experience without a subject. In Ankersmit's words: 'We die a partial death at such moments since all that we are is then reduced to just this feeling or experience' Ankersmit. ${ }^{1}$ So, the moment of experience is the moment in which you-your context, your language, and your identitydisappear from the "place" where only remains the experience.

In one sense, you must lose yourself in order to be in touch with the authentic past. But, when you become aware of having that direct 
encounter with come part of the past, that's when you don't have it anymore. It just slipped through your hands. That is why he associates historical experience with the experience of loss. This is also the tragic or romantic feature of experience that made the Ankersmit of SHE an "incurable sentimentalist" and an existentialist. Sometimes, we become aware of the real value of something we had after we lose it.

In the same manner, that is when history comes in. In Ankersmit's words: 'the entrance of history on the scene is ordinarily associated with a more and less sudden dramatic and/or tragic event that made us regard what was prior to it with a sense of profound loss' Ankersmit. ${ }^{4}$ History or representation comes in when the past or the (dramatic) historical experience goes out. Many historians believe, for example, that contemporary history (and 'the French people', in Michelet's view) came into being only with the French Revolution.

That is the point of the following statement by the American historian-philosopher Arthur Danto (very central to Ankersmit, so he quoted this many times in his writings): And something of the same sort is true for the historical period considered as an entity. It is a period solely from the perspective of the historian, who sees it from without; for those who lived in the period it would be just the way life was lived. And asked, afterwards, what it was like to have lived then, they may answer from the outside, from the historian's perspective. From the inside there is no answer to be given; it was simply the way things were. So when the members of a period can give an answer in terms satisfactory to the historian, the period will have exposed its outward surface and in a sense be over, as a period. Ankersmit. ${ }^{1}$

For thinkers like Danto or Ankersmit, there is no purpose in asking 'what is the meaning of life?', for life has no meaning. Life comes first, while meaning comes after. Perhaps we can teleologically speak about 'the purpose of life'-the one you pursue every single day of your life or the one you believe will take place in the future, or in the eternity. But the meaning of life only arises when life (or, at least, one part of it) no longer exists. For, life tells us no stories about itself. In Louis Mink's famous words, 'stories are not lived, but told'. And he goes on saying that: 'Life has no beginnings, middles, or ends; there are meetings, but the start of an affair belongs to the story we tell ourselves later, and there are partings, but final partings only in the story' Mink. ${ }^{5}$

Using Danto's words in the passage I just quoted, history (as much as historical periods, narrative substances or representations), then, is what you have when you look life from without (or indirectly, thorough the sources). The outsiders are those who can have a perspective on the way things were, on how should we call them-that was the French Revolution, or that was World War I, etc.-, or (most important) what kind of sense can we make of them. But the insiders are those who lived them and saw the things from within while experiencing life. For them, the good and bad, the fortunes and misfortunes of life were 'simply the way things' were. The present life is 'timeless', as Ankersmit ${ }^{2}$ would put it, or senseless, as I would add.

But-following Ankersmit's ${ }^{6}$ argument in a recent paper (2017)'then it may happen that we'll be captivated later by a longing (like a profound nostalgia) for what was "timeless" in that past, to that timeless past'. If we ask ourselves that question, we have placed ourselves in the realm of sublime historical experience. For one may say that there's nothing counterintuitive about simply being inside and living life. But when it comes to the past, how can one be "inside" or "look from within"? Ankersmit's answer came by the use he made of
Huizinga's notion of 'historical sensation'. We can say that Huizinga (and Ankersmit alike) was talking about something different from 'historical awareness', 'historical imagination' or things like that since those are-as much as historical representation-acts of association or a look from without. On the other hand, the historical sensation is seeing, feeling, touching and hearing 'from within' (the contact with the past). It is 'a momentary flesh in the minds of historians possessing an unusually acute sense of history' Ankersmit. ${ }^{4}$

In this sense, Huizinga (in a passage Ankersmit also quoted many times) explained that: 'This contact with the past, that is accompanied by the absolute conviction of complete authenticity and truth, can be provoked by a line from a chronicle, by an engraving, a few sounds from an old song'. Huizinga observed that this is not 'an element that the author writing in the past deliberately put down in his work. It is "behind" and not "in" the book that the past has left us' Apud Ankersmit. ${ }^{1}$

The same performance of identification with past reality is what Ankersmit-following Huizinga-now calls historical experience. But, as he sought to let clear, this identification with reality is not 'a triumph of the self over reality but rather a "pathos", a passive submission and complete receptivity to it". So, in the acts of association-like historical writing and historical representation-the historian has an active role to play; while in the moment of dissociation, he is in a passive position. Hence, as Ankersmit continues to explain, the: Sensation is momentary and has little or no duration; it is abrupt and cannot be predicted. It is accompanied by a sense of anxiety and of alienation: the direct experience or sensation of reality provokes a loss of the naturalness of even the most trivial objects. This explains why sensation is so enigmatic and why the right words seem to fail us for describing its content: experience here precedes language and the whole complex web of associations that are embedded in language. [...] Sensation effects a fissure in the temporal order so that the past and the present are momentarily united in a way that is familiar to us in the experience of 'déjà vu' Ankersmit. ${ }^{\text {' }}$

For some of the Ankersmit's readers (and maybe for Ankersmit himself), I might be now about to commit a great philosophical "heresy", by relating historical experience to 'religious experience'. But, as Huizinga himself admitted, historical experience (or sensation) has a 'world of its own'; and 'it is not like the enjoyment of the work of art, nor a religious affect, nor a trembling before the confrontation with nature, nor a recognition of a metaphysical truth, but yet a member of this series' Apud Ankersmit. ${ }^{1}$ So, I am not trying to merely 'mix the worlds' here, but only asking what do they have in common, and what can one learn from the other. [So, I will go directly to my main point now].

The consequence we just saw in Ankersmit's words I just quoted is, in my opinion, the foremost common ground between historical and religious experience, which is: the impossibility of finding the right words to describe the content of this experience (or to translate it into language or discourse). If this is a most regrettable feature of the Ankersmitean kind of experience-according to the 'acceptable' standards of narrativist philosophy, representationalism and historiography in general -, it should be, in my view, the most welcomed feature of the religious one. Let me explain why.

Firstly, I would say that not only history but also religion (as much as it is a form of discourse) works within the categories of association and dissociation, or (even more) of mediation (then role of priests, 
might be an example) and what is immediate (i.e., the direct contact between the pious or the believers and their God). In a broad sense, "experiencing God" precedes the talk about God. And religion is all about talking, domesticating, institutionalizing, and ritualizing the socalled 'religious experience' of the pious; one might even say that religion is experience + organization. But, an organized experience might still be an experience (in the sense we've been talking about untill now)? Perhaps Ankersmit would say: 'well, yes, a but a very poor kind of experience'. For the "richer" form of experience (sublime experience) is irretriaveble.

The point here is: religion is an associative activity. Its purpose is to connect or reconnect people with the Sacred, the Divine or the Transcendent (whatever name you prefer). It presupposes a previous connection, and it keeps existing thanks to people's need for mediators, representants or (as Ankersmit would also put it) 'substitutes'. When the God of the Bible got tired from all the means of 'representation' or substitution of himself on earth-in other words, when he got sick of its 'religion'-he incarnated himself in his Son, Jesus Christ, and then 'the Word became flesh', in St. John's words.

One might observe that this is a work of revelation (God revealed himself), but still through some form of association, in this case: the association of his Eternal 'non-existence' to a human existence (John Caputo once said that God 'doesn't exist, God insists', by means of always getting involved with this existence). And then Jesus said, again in St. John's words: 'who sees me sees the Father'. But who else, apart from Jesus, can really see God? Only God himself can see God, and only God himself can rid us from the other pretenders in the business of 'seeing God'. That is a great difference between seeing and pretending to see.

But there is also a great difference between the 'spiritual senses' or 'ultimate concerns' (as Paul Tillich would call) and what we may call the 'spiritual speech' or language, which is as big as the difference between historical experience and historical representation (in Ankersmit's work), or between dissociation and association. Let me give one last example here.

In his book The Great Divorce, C. S. Lewis wrote a story about a group of passengers who suddenly saw themselves in a bus excursion from hell to some other place, which happens to be the foothills of heaven. Those people in the bus were revealed to be 'ghosts', who in heaven met some 'shiny and happy people', men and woman, called 'spirits' (to be distinguished from the ghosts). And these spirits offered themselves to assist the ghosts from hell on a journey towards the mountains and the sunrise of heaven, ir order to show what kind of eternal life they could have if they repent and turn themselves to God. One of the ghosts (who was a well-known painter in his earthly life), amazed by the stoning beauties of that prodigious place, said:

1. 'I should like to paint this!'.

2. Then, one of the spirits warned him: 'I shouldn't bother about that just at present if I were you'.

3. But the ghost insisted: 'Look here; isn't one going to be allowed to go on painting?'

4. 'Looking comes first', replied the spirit.

5. 'But I've had my look. I've seen just what I want to do. God! I wish I had thought of bringing my things with me!'
6. The Spirit shook his head, scattering light from his hair as he did so. 'That sort of thing is no good here', he said.

7. 'What do you mean?' said the Ghost.

8. 'When you painted on earth-at least in your earlier days-It was because you caught glimpses of Heaven in the earthly landscape. The success of your painting was that it enabled others to see the glimpses too. But here you are having the thing itself. It is from here that the messages came. There is no good telling us about this country, for we see it already.' Lewis my adaptation.

This story reminds me of a biblical story, told by St. Paul in his II Corinthians, about a men who (whether in the body or out of the body, Paul could not tell) 'was caught up into paradise, and heard unspeakable words, which it is not lawful for a man to utter'. He does not say that the man couldn't speak about those words because it was forbidden, but because they were 'unspeakable'-like the words, the acts and the sights of any experience of this sort (a sublime experience). You can be inspired and transformed by it, but cannot contain it. This experience has you more than you can have it, paraphrasing Ankersmit.

Then, like the spirit (in Lewis' story) told that ghost that there was no good in painting those heaven's landscapes-because he already had 'the thing in itself', so what else could be more important? -, or like what Paul told about the 'unspeakable words' that the man heard in his sublime encounter with God in the 'Third Heaven', Ankersmit is now presenting a double alert both to practitioners of history and religion is:

a. First, the alert to what lies beyond the acts of association and representation of reality: the 'transcendent' and unknown world of the sublime, to which one may have 'access' if one is sensible enough to this kind of experience-as was Huizinga's case;

b. second, to the fact that there is no good in trying to express the content of this experience in language, for it cannot be "contained" in it-except through those 'glimpses of Heaven in earthly landscape' (what we would call the historical, or theological, or philosophical, 'talent' or 'insight'), enabling others to see something beautiful about 'the thing', although not 'the thing in itself'.

Therefore, if someone (perhaps following Magritte's counterexample in art, that is, evoking the illusion of viewing reality itself through the painting, instead of seeing the painting) still wants to claim about his or her 'painting': 'yes, it contains the thing', or it corresponds to it-not following, then, the humbler approach suggested by what we may call here the unattainability of experience -, then he or she, like Adam and Eve in the Genesis, will be seduced again by the Sneak's temptation, which says: 'You shall be like God!', or like gods. And that's the perfect way of proclaiming God's (or the religious experience's) death.

\section{Acknowledgments}

Paper presented at a conference during the "Science week" of the Faculty of Arts and Letters (Catholic University in Ruzomberok, Slovakia), on November 6 th, 2017. Funding was provided by CAPESPDSE, Brazil, grant no. 88881.134902/2016-01. 


\section{Conflict of interest}

The author declares no conflict of interest.

\section{References}

1. Ankersmit, Frank. Sublime Historical Experience. USA: Stanford University Press; 2005.

2. Ankersmit, Frank. Narrative Logic: The Semantics of Historian's Language. Netherlands: Martinus Nijhoff Publishers; 1983.
3. Ankersmit, Frank. A Escrita da História: A Natureza da Representação Histórica. 2nd ed. Brazil: Eduel; 2016.

4. Ankersmit, Frank. Meaning, Truth and Reference in Historical Representation. USA: Cornell University Press; 2012.

5. Louis O Mink. History and Fiction as Modes of Comprehension. New Literary History. 1970;1(3):541-558.

6. Ankersmit, Frank. Individuele en Collectieve Nostalgie, Groniek (forthcoming). 2017.

7. Lewis CS. The Great Divorce. USA: Collier Books; 1984. 